\title{
Goals and Proceedings Information
}

Indiana STEM Education Conference Goals

The goal of the annual Indiana STEM Education Conference is to support K-12 STEM learning opportunities in Indiana by sharing effective practices in STEM teaching and learning. The conference is an opportunity for STEM teachers, schools, researchers, and organizations to present instructional strategies, lessons/curriculum, policies, research, and resources. Each annual meeting is informed by a timely theme and is organized around four strands: STEM Instructional Strategies, STEM Curriculum and Resources, STEM Career Exposure, and STEM Education Research.

Proceeding Editors

William S. Walker, III, Lynn A. Bryan, S. Selcen Guzey, and Elizabeth Suazo-Flores

Recommended Citation

Author, A. A., \& Author, B. B. (2021). Title of article. In W. S. Walker, III, L. A. Bryan, S. S. Guzey, \& E. Suazo-Flores (Eds.), Proceedings of the 6th annual Indiana STEM Education Conference.

Purdue University: Purdue e-Pubs.

Articles published in the proceedings are copyrighted by the authors. Permission to reproduce an article or portions from an article must be obtained from the authors. 